\title{
Behavioral Intention to Adopt Islamic Banking in Pakistan: A Study Based on Theory of Planned Behavior
}

\author{
Shahab Aziz ${ }^{1 *}$, Zahra Afaq ${ }^{2}$, Uzma Bashir ${ }^{3}$ \\ ${ }^{1}$ PhD Scholar, Azman Hashim International Business School, Universiti Teknologi Malaysia, \\ Kuala Lumpur, Malaysia \\ ${ }^{2}$ MS Scholar, Foundation University, Islamabad, Pakistan \\ ${ }^{3} \mathrm{PhD}$ Scholar, Pakistan Institute of Development Economics (PIDE), Islamabad, Pakistan
}

\section{Keywords}

Islamic Banking Adoption TPB

Behavioural Beliefs

Control Beliefs

Normative Beliefs

Received: 10 August 2018 Accepted: 04 September 2018

\begin{abstract}
The current study aims to examine the behavioural intentions to adopt Islamic banking in Pakistan. The proposed model is grounded on 'Theory of Planned Behaviour (TPB)' which is widely applied in consumer behaviour studies. This theory comprises behavioural, normative and control belief structures which shape consumers' intentions. The data collection was carried out from two cities of Pakistan, Islamabad and Rawalpindi, through survey from 186 individuals. For data collection, non-probability, judgmental sampling technique has been used. The data has been analysed by using Partial Lease Squares Structural Equation Modelling (PLS-SEM) technique. The result of the study reveals that behavioural, normative and control beliefs are significant determinants of adoption of Islamic banking in Pakistan. It has been found that behavioural beliefs are very important for Islamic banking adoption. However, control beliefs appear to be the most significant in adoption of Islamic banking.
\end{abstract}

KAUJIE Classification: K0, V12, L25, N0

JEL Classification: C1, G21, G24, D61, D63, V12

(C) 2018 JIBM. All rights reserved.

\section{INTRODUCTION}

Banking might played a vital role in uplifting the economy of the developing nations. However, its legitimacy has been questioned on Islamic principles and is considered against the teachings of Islam. Islamic banking, which means intermediation according to Islamic principles, is the substitute of conventional banking. It has emerged as a rapidly growing industry (Abdullah \& Dusuki, 2006) and is gaining momentum in its reception and acceptance in Muslim as also non-Muslim countries (Atkinson \& Messy, 2011; Iqbal \& Molyneux, 2005). The driving force behind it is that it is both religiously and ethically appealing for being free from riba $\bar{a}$, gambling and speculative risk taking (Amin, Rahman, \& Razak, 2014). Ethically,

\footnotetext{
*Corresponding author: Shahab Aziz

†Email: shahabaziz7@ hotmail.com
} 
the Islamic banks refrain from funding any unlawful business. The Islamic banks also share the risks and rewards of any business transaction in a more fair and just manner. Islamic banking is thus an important and well-established domain of the financial services industry. Statistics reveal that around 775 Islamic financial institutions are operating around the globe amongst which 220 are operating as Islamic Window (Edbiz, 2015). It is expected that the volume of Islamic assets will reach $\$ 3.8$ tn by 2022 (World Bank Group, 2018).

The advent of Islamic Banking in Pakistan in its current structure was marked in the year 2002 since when it is functioning in parallel with the conventional banking. Pakistan has been striving hard for promoting and endorsing Islamic Banking (Majeed \& Zainab, 2017). According to the Islamic Banking Bulletin (2017), there are five full-fledged Islamic banks and sixteen stand-alone Islamic banking services units of the conventional banks operating in Pakistan. . The share of Islamic banking products in the industry is $12.4 \%$ and $14.5 \%$. In terms of branches, a total of 2581 branches of Islamic banks are operating across the country. Most of the branches are in Punjab (47.8\%). Details of full-fledged Islamic banks including the number of branches and year of establishment are outlined in Table 1 below.

TABLE 1

Islamic Banks and Subsidiary

\begin{tabular}{lll}
\hline \hline Name of Bank & Year of Establishment & No of Branches \\
\hline Meezan Bank & 2002 & 601 \\
BankIslami Pakistan Ltd & 2006 & 218 \\
Dubai Islamic Bank Pakistan Ltd & 2006 & 200 \\
Albaraka Bank Pakistan Ltd & 2010 & 180 \\
MCB- Islamic Bank Ltd (Subsidiary) & 2015 & 76 \\
\hline \hline
\end{tabular}

Source: State Bank of Pakistan (2017)

Although the number of the branches of banks is promising, the growth of Islamic Banking is relatively slow with a considerably lower market share. This increases skeptism regarding the adoption of Islamic banking especially where $97 \%$ of the population are Muslims. For this purpose, the present study takes an initiative to analyse the issue by examining the behavioral aspects of Islamic banking adoption. The behavioral understanding of the potential customers provides many implications for the Islamic banking industry to devise effective marketing strategy with a clear understanding of the consumers' demographic and behavioral profiles

\section{Objectives}

The research study purposes find out the factors which lead to the choice of Islamic banking. Specifically, it is to find out answer to the following questions:

i. What is the effect of attitude on adoption of Islamic banking?

ii. What is the effect of subjective norms on adoption of Islamic banking?

iii. What is the effect of perceived behavioral control on adoption of Islamic banking?

This study explains the consumer's intention to adopt the Islamic banking in Pakistan using the predictors of adoption intention of Islamic banking services. It seeks guidance 
from the TPB as it provides a robust framework supported by previous literature which will aid in predicting the consumer intentions related to adoption of Islamic banking services.

\section{LITERATURE REVIEW}

\section{Theoretical Criticism}

Intention behavior theories have long been studied in marketing and consumer behavior. The theories are mainly used to study behavioral elements that might affect consumer choices decisions. Fishbein and Ajzen, (1977) presented the Theory of Reasoned Action (TRA) which is widely used to study human intention and concerns a person's behavior and motivation to carry out a certain act and aids in explaining and predicting human behaviour. There are two assumptions in TRA i.e., majority of the human astions are driven by volitional control and determined by their behavioral intentions (Fishbein \& Ajzen, 1977).

TRA originated from psychology and has been used in many disciplines to explain human behaviour (Lada, Tanakinjal, \& Amin, 2009; Law, 2010; Ramayah, Lee, \& Mohamad, 2010). In the marketing domain, TRA has been used in studying intention to purchase halal products (Lada et al., 2009), green products (Ramayah et al., 2010) and luxury products (Summers, Belleau, \& Xu, 2006). TRA has also been used in financial services context to study consumer behaviour (Amin \& Chong, 2011; Omar, 2007; Omar \& Owusu-Frimpong, 2007). There are three constructs that constitute TRA, i.e., behavioral intention, attitude and subjective norms. According to this theory, intention results in behavior and such intention is termed as behavioral intention which is formed by individual's attitudes and subjective norms.

However, TRA has been criticized due to certain limitations that led to the incorporation of the TPB in consumer behaviour. TPB extends TRA (Fishbein \& Ajzen, 1977) and is considered as a very one dominant conceptual framework for studying human behaviour (Ajzen, 2001). It has a background from social psychology and concerns the connection of beliefs with behavior (Azjen, 1991). TPB is an extension of TRA and integrates the behaviour influenced by by non-voluntary exogenous variables (Ajzen, 1985). It is comprised of four components which are behavioural intentions, attitude, subjective norms and perceived behavioural control (Figure 1). Out of these four constructs, attitude, subjective norms and perceived behavioral control identify the intention to adopt Islamic banking in Pakistan. It extends TRA by including perceived behavioral control that takes into account the volitional factors for examining the likelihood of the human behaviour (Conner \& Armitage, 1998) apart from the attitudes and subjective norms.

\section{Attitude and Intention}

Attitude is a fairly persistent set of beliefs, feelings and behavioural tendencies about objects, groups, events, or symbols that are significant socially (Vaughan \& Hogg, 2005). It is also a psychological trend expressed in terms of favoring or disfavoring any entity (Eagly \& Chaiken, 1993). According to Suki (2010), attitude indicates the extent to which a person assesses an entity as being favorable or unfavorable. Attitudes help in predicting people's 
intentions and behaviours (Phau \& Teah, 2009). It has been proved that attitudes influence behaviours. When people are offered with different options to choose, people opt the one which has a higher consideration (Arvola, Lähteenmäki, \& Tuorila, 1999). Previous literature has proved that attitude influences the choice of products or services (Jamal \& Ahmed, 2007; Taib, Ramayah, \& Razak, 2008).

Literature on attitude and intention is very vast and depicts its strong influence on behavioral intention. The studies have not only been conducted in Islamic financial services context, but concerning integration of technology and general consumer behavior as well. Ali and Jama (2016) reported the influence of attitude on intention in Islamic Insurance context; Md Husin and Rehman (2016) Wahyuni and Arifin (2013) argued on the importance of attitudes on intention in Islamic Banking context; Gopi and Ramayah (2007) discussed attitude and intentions with respect to online trade; Ramayah and Suki (2006) argued on the importance of attitude and intention in the technology integration in learning curriculums. So, on the basis of the past evidence, it can be said that stronger attitude leads to stronger behavioral intentions to purchase. However, some studies have found a negative relationship between attitude and behavioral intentions (Al-Jabari, Othman, \& Nik Mat, 2012) in the context of breast cancer screening; Armitage (2005) in the context of physical activity; Omer (2007) in the context of life insurance. The review of the extant literature provides guidance for further exploration for this phenomenon in the Islamic Banking context. For that purpose, it is hypothesized as follows:

H1: Attitude positively influences the intention of adoption of Islamic banking.

\section{Subjective Norms and Intentions}

Subjective norms are termed as the impact of social factors i.e. social pressure exercised to exhibit or not to exhibit a certain behavior (Fishbein \& Ajzen, 1977). In some situations, the social pressures dominate attitude towards certain behaviours (Fishbein \& Ajzen, 1977). Subjective norms comprises of the underlying belief structures called normative beliefs and motivation to observe those beliefs. Normative beliefs are an individual's perception that a certain referent group influences them to perform, while motivation to comply is the importance of those referent groups. Subjective norms are the sum of normative beliefs and the weight given to those beliefs.

Some studies have shown that subjective norms have minimum effect on behavioural intentions (Bagozzi, Wong, Abe, \& Bergami, 2000). However, the phenomenon still needs to be explored further even though in literature there are conflicting results regarding the relationship between normative belief structures and behavioural intentions. Studies carried out by Echchabi and Aziz (2012), and Pedersen (2005) have indicated that subjective norms importantly predict an individual's intentions. In financial services, the subjective norms have also been proved to significantly predict the consumers intentions (Siang \& Weng, 2011).

Studies carried out in multiple disciplines have shown significant results of subjective norms on behavioural intention. For example, in Islamic insurance (Amin, 2012; Omar \& Owusu-Frimpong, 2007), Islamic house finance products (Ali \& Jama, 2016; Amin et al., 
2016), internet banking (Amin, 2012; Juwaheer, Pudaruth, \& Noyaux, 2012; and Nor, 2013) and home financing (Razak \& Abduh, 2012). However, in contrast to previous literature, few studies, as conducted by Md Husin and Rahman (2016) and Saeed, Juell-Skielse, and Uppström (2012) have found that subjective norms do not determine behavioural intentions. The conflicting results in previous studies show its importance to carry out more studies. Since the current research is being carried out in the Islamic Banking domain; therefore;

H2: Subjective norms have a positive influence on an individual's intention of adopting Islamic banking.

\section{Perceived Behavioural Control and Intention}

Perceived Behavioural Control (PBC) is "any person's belief as to how easy or difficult performance of the behaviour is likely to be" (Ajzen \& Madden, 1986, 457). TPB explains that attitudes, subjective norms and $\mathrm{PBC}$ together determine behavioural intentions. The more favourable attitude and subjective norms along with greater $\mathrm{PBC}$ will lead to stronger behavioural intentions to perform certain behaviour.

Behaviour is shaped by both motivation and the ability to perform a certain act. If a person does not have the ability or the resources to perform a particular task, it is very likely that he will not intend to do it (Ajzen, 1989; Schifter \& Ajzen, 1985). According to Madden, Ellen, and Ajzen (1992), individuals lacking in sufficient resources or information to perform a certain behavior will show lower intentions to perform that task despite showing an encouraging attitude and subjective norms.

In literature, previous studies have shown mixed results regarding PBC and behavioural intention relationship. Past studies carried out in Islamic banking by Echchabi (2012); Echchabi and Aziz (2012); Md Husin and Rehman (2016); in Islamic Insurance by Ali and Jama (2016); in internet banking services by AL-Ajam and Nor (2013); in resource planning adoption by Echchabi and Aziz (2012), and Saeed et al., (2012); and in credit card use by university community by Sari \& Rofaida (2011), have found a positive relationship between PBC and behavioural intentions. However, a few studies have failed to establish any significant relationship between PBC and intentions, like that of Taylor and Todd (1995) in technology adoption; and Beiginia, Besheli, Soluklu, and Ahmadi (2011) in mobile banking adoption. In Islamic banking adoption most studies have reported a positive relation of PCB with intention. In the Pakistani context, where Islamic banking adoption is relatively in its initial stages, it is hypothesized as below:

H3: Perceived behavioural control positively influences individual's intention of adopting Islamic banking. 


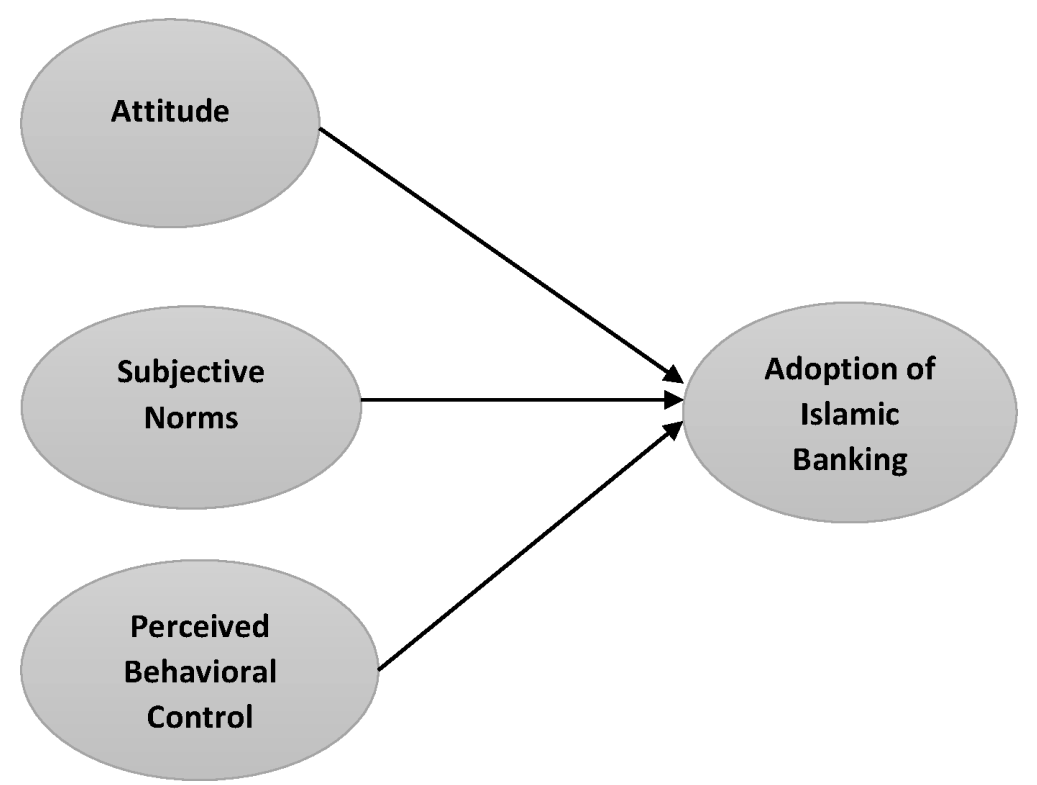

FIGURE 1. Conceptual framework based on TPB

\section{RESEARCH DESIGN}

The unit of analysis of this study are the individuals avaling banking facilities in both Islamic and conventional banks. The reason for choosing such unit of analysis is that the respondents who availed both types of banking would be able to better distinguish between both kinds of banking services, and their still using conventional banking along with Islamic banking might be showing lack of confidence in fully adapting to Islamic banking. Those who are just using conventional banking are important component to find out their likely drivers which can create intentions to adopt. Those who are using only Islamic banking are important to provide their important factors of adoption. The data have been collected from two cities namely Rawalpindi and Islamabad primarily due to three reasons. Firstly, Islamabad and Rawalpindi are twin cities consisting of a total population which comprises of people belonging to different ethnic groups. Additionally, the high literacy rate and the availability of the banking services in these areas make Islamabad and Rawalpindi appropriate for data collection.

$\mathrm{G}^{*}$ power table was used for appropriate sampling size for this study (Hair, Sarstedt, Hopkins, \& Kuppelwieser, 2014). The effect size is 0.15, and power is 0.95. Sample size of 129 was acquired according to this criterion. The authors chose the study's sample size to be 186 according to the past literature (Hair et al., 2014; Yeap et al., 2016). There is no data available for individual's comprising the unit of analysis for the present study. Hence no sampling frame exists which leads to the choice of non probability sampling for the current study. Non probability sampling technique, judgmental sampling been employed for the current research as unit of analysis have certain attributed which needs to be fulfilled.

The items for each construct in the questionaire were taken from the previous liteature and were adapted according to the Islamic banking context. Some of the items have been taken from the pioneer work of Davies (1989), Taylor and Todd (1995), and some are taken 
from literature, e.g., Al-Majali and Nik Mat (2010); Beigina et al. (2010), Fisher and Chu (2009), Lin (2005), Ndubisi (2004), Puschel, Mazzon and Hernandez (2010), Rammal and Zurbruegg (2007), Sharma and Bock (2005), Shih and Fang (2004), Tan and Teo (2000), Teo and Pok (2003), To, Liao, Chiang, Shih, and Chang (2008) and Williams (2009). The items for all the constructs has been validated in the previous studies and have been used extensively in the previous empirical studies.

The data collection was carried out through a survey questionnaire having two sections. The first section consisted of the specific item sets for different constructs used in the theoretical framework and the items were adapted from the existing literature with liket scale 1 to 7 to fit the context of current study. The second section of the questionnaire has the demographic questions. 250 questionnaires were distributed and 200 reponses were returned. Due to suspecious responses, 14 survey questionnaires were discarded which left 186 usedable questionnares for data analysis.

\section{Respondents' Profile}

Out of 186 respondents, 120 were male, and 66 female. In term of marital status, 74 people were single, while 112 people were married. 104 respondents had a master's degree. 54.8\% respondents worked in private sector organizations. Additionally, $85.5 \%$ respondents were below the age of 40 years. In addition to that, $38.7 \%$ used Islamic banking where as $34.9 \%$ used conventional banking.

TABLE 2

Demographic profile of the respondents

\begin{tabular}{lllll}
\hline \hline Demographic & & Number of Respondents & Percent & Cumulative percent \\
\hline Gender & Male & 120 & 64.5 & 64.5 \\
Age & Female & 66 & 35.5 & 100 \\
& 21-30 years & 88 & 47.3 & 47.3 \\
& 31-40 years & 71 & 38.2 & 85.5 \\
Occupational Status & A1-50 years & 18 & 9.7 & 95.2 \\
& Pbove 50 years & 9 & 4.8 & 100 \\
& Public Sector & 50 & 26.9 & 26.9 \\
& Private Sector & 102 & 54.8 & 81.7 \\
& Self Employed & 16 & 8.6 & 90.3 \\
Marital status & Student & 14 & 7.5 & 97.8 \\
& Other & 4 & 2.2 & 100 \\
& Single & 74 & 39.8 & 39.8 \\
& Married & 112 & 60.2 & 100 \\
& Diploma & 4 & 2.2 & 2.2 \\
& Professional & 20 & 10.8 & 12.9 \\
& Bachelors & 47 & 25.3 & 38.2 \\
& Masters & 104 & 55.9 & 94.1 \\
Banking & Phd & 11 & 5.9 & 100 \\
& Islamic Banking & 72 & 38.7 & 38.7 \\
& Conventional Banking & 65 & 34.9 & 73.7 \\
& Both & 39 & 21.0 & 94.6 \\
& None & 10 & 5.4 & 100 \\
\hline \hline
\end{tabular}




\section{Structural Equation Modeling}

The analysis of the data was done with the help of PLS-SEM procedure. For that purpose Smart-PLS version 3.2.7 software was used for the advantage of handling non-normal data and because the authors needed to explain the variance among the target variables. PLSSEM is carried out in two phases. In the first phase, the measurement model or the outer model is assessed in which the reliability of the data and its validity is checked. Following the assessment of the measurement model, structural model assessment was carried out for hypothesis testing. The path model constructed is shown in Figure 2.

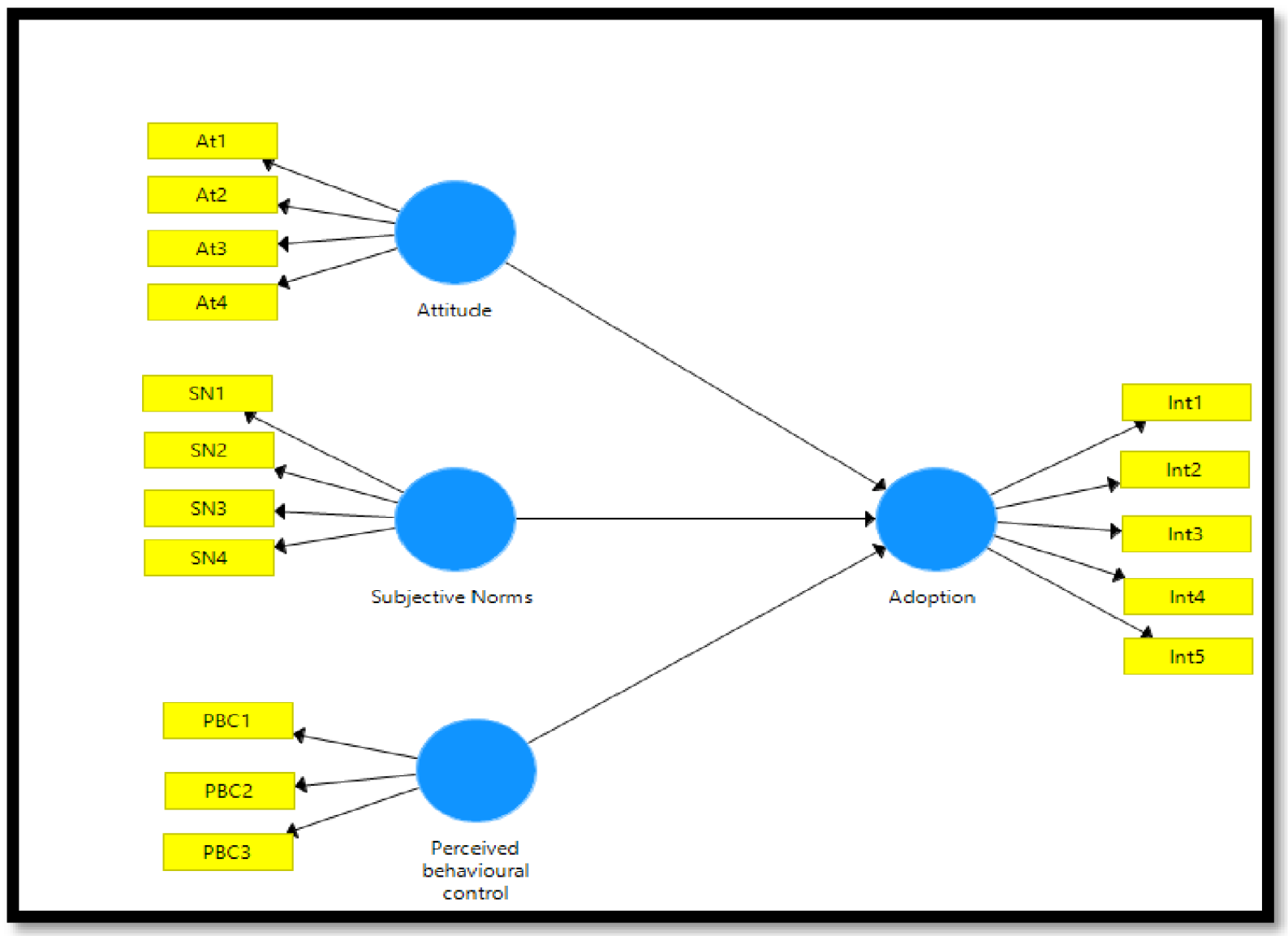

FIGURE 2. Path model in SmartPLS (PLS-SEM)

\section{Measurement Model}

Measurement model assessment is the first step of the structural equation modelling. It reveals the relation of the variable with its items. It can be checked through the assessment of the factor loadings which is also known as internal reliability, composite reliability which calculates the internal consistency, construct validity (AVE) and discriminant validity calculated by Fornell and Lacker criterion as well as HTMT ratio. The measurement results were obtained after running algorithm in smartPLS. 
TABLE 3

Validity and Reliability for Constructs

\begin{tabular}{lllll}
\hline \hline Constructs & Items & Loading & AVE & CR \\
\hline Adoption & Ad 1 & 0.911 & 0.874 & 0.972 \\
& Ad 2 & 0.959 & & \\
& Ad 3 & 0.952 & & \\
Ad 4 & 0.954 & & \\
Attitude & Ad 5 & 0.904 & & \\
& Att 1 & 0.830 & 0.825 & 0.949 \\
& Att 2 & 0.938 & & \\
Subjective Norms & Att 3 & 0.935 & & \\
& Att 4 & 0.925 & & \\
& SN 1 & 0.932 & 0.865 & 0.962 \\
& SN 2 & 0.935 & & \\
SN 3 & 0.934 & & \\
Perceived Behavioural Control & SBC 1 & 0.939 & 0.823 & 0.933 \\
& PBC 2 & 0.912 & & \\
\hline \hline
\end{tabular}

Table 3 shows the summary of measurement model assessment. Factor loadings for all the constructs exceed the set benchmark of $0.7, \mathrm{CR}$ is also above 0.7 and AVE loadings are above 0.5 as well. Hence instituting IR, IC and CR for the constructs used in the model.

Further, for the discriminant validity evaluation, Fornell and Larcker (1981) criterion was employed (Hair et al., 2014). Fornell and Larcker (1981) parallels the AVE of each construct with the correlations of the other constructs. For the current study, the square root of AVE of every construct had a greater value than its correlations with other constructs. Apart from that HTMT also establishes discriminant validity with cut off value that should less than 0.90 as shown in Table 5. The measurement model of this study ensured an adequate discriminant validity. Therefore, as the measurement model had a satisfactory reliability and validity, the analysis of the structural model could be furthered.

TABLE 4

Discriminant Validity

\begin{tabular}{lllll}
\hline \hline Constructs & 1 & 2 & 3 & 4 \\
\hline Adoption & $\mathbf{0 . 9 3 5}$ & & & \\
Attitude & 0.852 & $\mathbf{0 . 9 0 8}$ & & \\
Perceived behavioural control & 0.666 & 0.681 & $\mathbf{0 . 9 0 7}$ & \\
Subjective Norms & 0.749 & 0.721 & 0.654 & $\mathbf{0 . 9 3 0}$ \\
\hline
\end{tabular}

Diagonal values are the square root of the AVE while the off-diagonals are correlations. 
TABLE 5

HTMT

\begin{tabular}{lllll}
\hline \hline Constructs & 1 & 2 & 3 & 4 \\
\hline Adoption & & & & \\
Attitude & 0.898 & & & \\
Perceived behavioural control & 0.714 & 0.714 & & \\
Subjective Norms & 0.783 & 0.783 & 0.709 & \\
\hline \hline
\end{tabular}

\section{Structural Model}

After the analysis of the outer model (measurement model), the structural model was examined. It includes the models predictive relevance and the relationships among the reflective constructs. For that purpose, $R^{2}$ and $Q^{2}$ values were calculated. Table 5 shows that $R^{2}$ for adoption was $76 \%$ signifying that the model had an acceptable explanatory power. Apart from that, blindfolding technique was employed for the predictive relevance to assess the predictive relevance. Hair et al. (2014) said that blindfolding should be applied for endogenous variable having a reflective measurement. Values as per $Q^{2}>0$ shows an adequate predictive relevance and the $Q^{2}$ value for adoption was 0.622 as shown in Table 6 .

TABLE 6

Goodness of Fit and Predictive Relevance

$R^{2} \quad Q^{2}$

Adoption $0.763 \quad 0.622$

Effect-size $\left(f^{2}\right)$ is another criterion used for evaluating the structural model. $f^{2}$ inspects the unique outcome of each exogenous variable to the endogenous variable. Cohen (1988) stated that $f^{2}$ of $0.02,0.15$ and 0.35 are termed as small, medium, large respectively. Therefore, the effect size $\left(f^{2}\right)$ of attitude towards Islamic banking adoption is large, of subjective norms and perceived behavioural control is small s as shown in Table 7. Hence, we can say that the research model had an adequate predictive relevance.

The estimates were achieved for the path coefficients to test the hypotheses. Through PLS-SEM algorithm. Bootstrapping was done for 5,000 sample. Hypothesized relationships among the constructs are summarized in Table 7. H1 symbolized the relation between attitude and adoption of Islamic banking, which was supported with $\mathrm{B}=0.618, p<0.01$ and $t$ statistics 9.793. $\mathrm{H} 2$ showed the relation between subjective norms and adoption of Islamic banking which was supported with $\mathrm{B}=0.253, p<0.01$ and $t$ statistics 3.639. H3 revealed the relation between perceived behavioural control and adoption of Islamic banking which is also supported with $\mathrm{B}=0.083, p<0.01$ and $t$ statistics 1.590 . All three hypotheses were supported by the data analysis of the current study. 
TABLE 7

Hypothesis Testing

\begin{tabular}{lllllll}
\hline \hline Hyp & Relationship & Beta & Std Error & $t$-value & Decision & $f^{2}$ \\
\hline H1 & Att- $>$ Adopt & 0.618 & 0.063 & $9.793^{* *}$ & Supported & 0.652 \\
H2 & SN- $>$ Adopt & 0.253 & 0.069 & $3.639^{* *}$ & Supported & 0.118 \\
H3 & PBC-> Adopt & 0.083 & 0.052 & $1.590^{* *}$ & Supported & 0.014 \\
\hline \hline$p^{*}<0.05, p^{* *}<0.01$ & & & & &
\end{tabular}

\section{Model Fit}

For the model fit, smart PLS runs Standardized Mean Square Values (SRMR), while the cut threshold of model fit should be less than 0.080. For the current study, SRMR was measured to be 0.041 which was acceptable as it was under the maximum of 0.80 .

TABLE 8

\begin{tabular}{lc}
\multicolumn{2}{c}{ Model fit value } \\
\hline \hline Criterion & Value \\
\hline SRMR & 0.041 \\
\hline \hline
\end{tabular}

\section{Importance Performance Map Analysis}

The importance performance map analysis revealed that attitude was the most importance factor to determine the adoption of Islamic banking services. It was followed by subjective norms and perceived behavioural control. However, the performance of perceived behavioral control was the highest and was followed by attitude and subjective norms. Table 9 shows the results as follows

TABLE 9

IMPA Results

\begin{tabular}{lll}
\hline \hline Latent Variable & \multicolumn{2}{c}{ Intention to adopt } \\
\cline { 2 - 3 } & Total Effect (Importance) & Index Value (performance) \\
\hline Attitude & 0.668 & 59.33 \\
Subjective norms & 0.263 & 53.18 \\
Perceived behavioural control & 0.090 & 61.12 \\
\hline \hline
\end{tabular}

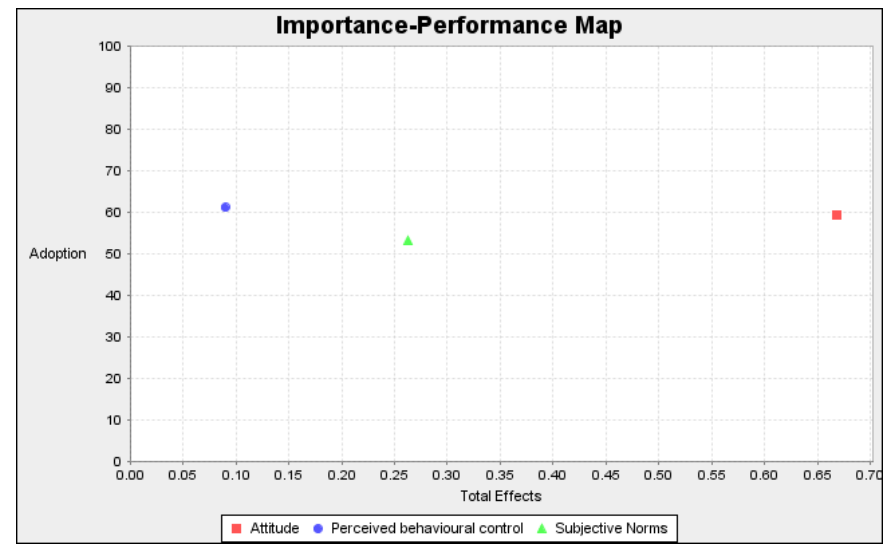

FIGURE 3. Importance performance map analysis 


\section{DISCUSSION}

This study has been carried out to understand whether attitudes, subjective norms and perceived behavioral control shape a positive intention in Islamic banks potential clientele to adopt Islamic banking system. Taking on a theoretical guidance from the TPB, three predictors have been empirically tested for their influence on the behavioural intention to adopt Islamic banking services.

The results of the study indicated that all the chosen constructs are significantly influencing the intention to adopt the Islamic banking services. Three hypotheses were formulated to address the objectives of the study. Hence, it hypothesized that attitude positively influenced the adoption of Islamic banking. The findings of this research have supported this testable statement. According to the results of this study, if a consumer has positive attitude towards adopting Islamic banking, he will also have a positive intention towards adopting the Islamic banking services. The results are in line with the previous literature (Ali \& Jama, 2016, Amin et al. 2016). The attitude has been found to be the most important predictor. This signifies that attitude plays an effective role to motivate a consumer to develop positive intention (Gopi \& Ramayah, 2007). It further signifies that the favorable attitude would increase the chances of Islamic bank customer using the product.

This study also aimed to find out whether the subjective norms positively influence the intention to adopt Islamic banking. The results proved to be in line with the previous literature (Ali \& Jama, 2016, Amin et al., 2016, Razak \& Abduh, 2012) positing a positive relation of subjective norms with intention to use Islamic banking Services. This means that the opinion of the people who are close to the potential consumer is also important in developing a positive intention for the adoption of Islamic banking services. The inadequate knowledge and lack of awareness makes a person count on the advice and support of his referent group. Subjective norms could be increased if the when the important people to the consumer are in favor of using the Islamic banking services.

\section{CONCLUSION}

The study has established that positive attitude, subjective norms and perceived behavioural control are the important indicators of adoption of Islamic banking in any society. The level of adoption has been low in Pakistan as Islamic banks have been unable to develop a positive attitude among the target population. This shows the lack of satisfaction among the existing customers of the Islamic banks. To enhance the customer base and to capture a substantial market share, several actions should be taken. First, Islamic banks need to launch such campaigns which can enhance and create a positive attitude among the target population as positive attitude is a significant determinant of adoption of Islamic banking. Second, Islamic banks need to enhance the level of quality services which will enable dissemination of positive word of mouth, which is also an important and significant determinant of adoption. 


\section{Theoretical Implications}

The results of this study provide precious theoretical implications by finding out that attitudes, subjective norms and perceived behavioral control not only influence the intentions of the people in Islamic banking and finance, but they also shape positive intentions for persons intending to use Islamic banking services.

\section{Practical Implications}

Practically implied, this study has interesting insights for the Islamic banking sector. Islamic banks outreach can be enhanced by efforts made at improving the perceived behavioral control measures. They can gauge on the attitudes, subjective norms and perceived behavioral control to ensure present customer retention and future consumer engagement. Those conventional banks, which wish to broaden up their customer base could introduce the Islamic banking services, could tap on the attitudes, subjective norms and perceived behavioral control of the prospective consumers and devise effective strategies to engage customer attention and ensure positive intentions to use Islamic banking services.

Positive attitude can be created through launching of awareness campaigns. These campaigns can be through electronic and print media along with arranging awareness programs by involving peers in communities. The focus of such campaigns should be increasing the awareness in terms of Sharī ah compliance of Islamic banking practices. To spread positive word of mouth, quality of services should be improved to enhance satisfaction of existing clients. It is because the satisfied clients can spread positive word of mouth which can bring in new clients for the Islamic banks.

\section{Future Research Direction}

The future studies can be carried out by collecting the data from more cities to increase the generalizability of the results across the country. The study has used the TPB while the attitude, subjective norms and perceived behavioural controls have been used as the main constructs. The future studies can be carried out while decomposing these belief structures and antecedents of these constructs can be incorporated within the model which will enhance the level of understanding from managerial perspective. Apart from that, a time lagged study could be conducted to ensure its robustness.

\section{REFERENCES}

Abdullah, N. I., Dusuki, A. W. (2006). Customers perceptions of Islamic hire-purchase facility in Malaysia: An empirical analysis. IIUM Journal of Economics and Management, 14(2), 177-204.

Al-Ajam, A. S., \& Nor, K. M. (2013). Influencing factors on behavioral intention to adopt Internet banking service. World Applied Sciences Journal, 22(11), 1652-1656.

Ali, A. Y. S., \& Jama, A. K. A. (2016). Determinants of Islamic insurance acceptance: Empirical evidence from Somalia. European Journal of Business and Management, 8(15), 102-108.

Al-Jabari, M. A., Othman, S. N., \& Nik Mat, N. K. (2012). Actual online shopping be- 
havior among Jordanian customers. American Journal of Economics, Special Issue, 125-129. doi: https://doi.org/10.5923/j.economics.20120001.28

Amin, H. (2012). Patronage factors of Malaysian local customers toward Islamic credit cards. Management Research Review, 35(6), 512-530.

doi: https://doi.org/10.1108/01409171211238271

Amin, H., \& Chong, R. K. (2011). Is the theory of reasoned action valid for Ar-Rahnu? An empirical investigation. Australian Journal of Basic and Applied Sciences, 5(10), 716-726.

Amin, H., Rahman, A. R. A., \& Razak, D. A. (2014). Consumer acceptance of Islamic home financing. International Journal of Housing Markets and Analysis, 7(3), 307332. doi: https://doi.org/10.1108/IJHMA-12-2012-0063

Armitage, C. J. (2005). Can the theory of planned behavior predict the maintenance of physical activity? Health Psychology, 24(3), 235-245. doi: https://doi.org/10.1037/02786133.24.3.235

Arvola, A., Lähteenmäki, L., \& Tuorila, H. (1999). Predicting the intent to purchase unfamiliar and familiar cheeses: The effects of attitudes, expected liking and food neophobia. Appetite, 32(1), 113-126. doi: https://doi.org/10.1006/appe.1998.0181

Atkinson, A., \& Messy, F. A. (2011). Assessing financial literacy in 12 countries: An OECD/INFE international pilot exercise. Journal of Pension Economics E Finance, 10(4), 657-665. doi: https://doi.org/10.1017/S1474747211000539

Bagozzi, R. P., Wong, N., Abe, S., \& Bergami, M. (2000). Cultural and situational contingencies and the theory of reasoned action: Application to fast food restaurant consumption. Journal of Consumer Psychology, 9(2), 97-106.

doi: https://doi.org/10.1207/S15327663JCP0902_4

Beiginia, A. R., Besheli, A. S., Soluklu, M. E., \& Ahmadi, M. (2011). Assessing the mobile banking adoption based on the decomposed theory of planned behaviour. European Journal of Economics, Finance and Administrative Sciences, 28(1), 7-15.

Conner, M., \& Armitage, C. J. (1998). Extending the theory of planned behavior: A review and avenues for further research. Journal of Applied Social Psychology, 28(15), 14291464. doi: https://doi.org/10.1111/j.1559-1816.1998.tb01685.x

Eagly, A. H., \& Chaiken, S. (1993). The psychology of attitudes. Orlando, FL: Harcourt Brace Jovanovich College Publishers.

Echchabi, A. (2012). The relationship between religiosity and customers' adoption of Islamic banking services in Morocco. Oman Chapter of Arabian Journal of Business and Management Review, 34(967), 1-6. doi: https://doi.org/10.12816/0002190

Echchabi, A., \& Aziz, H. A. (2012). Empirical investigation of customers' perception and adoption towards Islamic banking services in Morocco. Middle-East Journal of Scientific Research, 12(6), 849-858.

Edbiz, C. (2015). Global Islamic finance report. Retrieved from https://bit.ly/2EoxuU4 Fishbein, M., \& Ajzen, I. (1977). Belief, attitude, intention, and behavior: An introduction to theory and research. Journal of Business Venturing, 5, 177-189. 
Gopi, M., \& Ramayah, T. (2007). Applicability of theory of planned behavior in predicting intention to trade online: Some evidence from a developing country. International Journal of Emerging Markets, 2(4), 348-360. doi: https://doi.org/10.1108/17468800710824509

Hair Jr, J., Sarstedt, M., Hopkins, L., \& G. Kuppelwieser, V. (2014). Partial least squares structural equation modeling (PLS-SEM) An emerging tool in business research. European Business Review, 26(2), 106-121. doi: https://doi.org/10.1108/EBR-10-20130128

Iqbal, M., \& Molyneux, P. (2005). Thirty years of Islamic banking: History, performance and prospects. New York, NY: Palgrave Macmillan.

Jamal, A. S., \& Ahmed, A. F. (2007). Socio-cultural factors influencing consumer adoption of online transactions. In Eighth World Congress on the Management of eBusiness (pp. 5-5). Toronto, Canada. doi: https://doi.org/10.1109/WCMEB.2007.60

Juwaheer, T. D., Pudaruth, S., \& Noyaux, M. M. E. (2012). Analysing the impact of green marketing strategies on consumer purchasing patterns in Mauritius. World Journal of Entrepreneurship, Management and Sustainable Development, 8(1), 36-59. doi: https://doi.org/10.1108/20425961211221615

Lada, S., Tanakinjal, H. G., \& Amin, H. (2009). Predicting intention to choose halal products using theory of reasoned action. International Journal of Islamic and Middle Eastern Finance and Management, 2(1), 66-76.

doi: https://doi.org/10.1108/17538390910946276

Law, P. K. (2010). A theory of reasoned action model of accounting students' career choice in public accounting practices in the post-Enron. Journal of Applied Accounting Research, 11(1), 58-73. doi: https://doi.org/10.1108/09675421011050036

Madden, T. J., Ellen, P. S., \& Ajzen, I. (1992). A comparison of the theory of planned behavior and the theory of reasoned action. Personality and Social Psychology Bulletin, 18(1), 3-9. doi: https://doi.org/10.1177/0146167292181001

Md Husin, M., \& Ab Rahman, A. (2016). Predicting intention to participate in family takaful scheme using decomposed theory of planned behaviour. International Journal of Social Economics, 43(12), 1351-1366. doi: https://doi.org/10.1108/IJSE-03-20150074

Omar, O. E. (2007). The retailing of life insurance in Nigeria: An assessment of consumers' attitudes. Journal of Retail Marketing Management Research, 1(1), 41-47.

Omar, O., \& Owusu-Frimpong, N. (2007). Life insurance in Nigeria: An application of the theory of reasoned action to consumers' attitudes and purchase intention. The Service Industries Journal, 27(7), 963-976.

doi: https://doi.org/10.1080/02642060701570891

Pedersen, P. E. (2005). Adoption of mobile Internet services: An exploratory study of mobile commerce early adopters. Journal of Organizational Computing and Electronic Commerce, 15(3), 203-222. doi: https://doi.org/10.1207/s15327744joce1503_2

Phau, I., \& Teah, M. (2009). Devil wears (counterfeit) Prada: A study of antecedents and outcomes of attitudes towards counterfeits of luxury brands. Journal of Consumer Marketing, 26(1), 15-27. doi: https://doi.org/10.1108/07363760910927019 
Ramayah, T., \& Suki, N. M. (2006). Intention to use mobile PC among MBA students: Implications for technology integration in the learning curriculum. UNITAR e-Journal, 2(2), 30-39.

Ramayah, T., Lee, J. W. C., \& Mohamad, O. (2010). Green product purchase intention: Some insights from a developing country. Resources, Conservation and Recycling, 54(12), 1419-1427. doi: https://doi.org/10.1016/j.resconrec.2010.06.007

Saeed, I., Juell-Skielse, G., \& Uppström, E. (2012). Cloud enterprise resource planning adoption: Motives \& barriers. In Advances in Enterprise Information Systems II. Boca Raton, FL: CRC Press. doi: https://doi.org/10.1201/b12295-45

Schifter, D. E., \& Ajzen, I. (1985). Intention, perceived control, and weight loss: An application of the theory of planned behavior. Journal of Personality and Social Psychology, 49(3), 843-851. doi: https://doi.org/10.1037/0022-3514.49.3.843

Siang, L. C., \& Weng, L. K. (2011). Factors affecting non-muslim consumers' towards intention to use Islamic banking products and services. Paper presented at the Las Vegas International Academic Conference (pp. 15-17), Las Vegas, NV.

State Bank of Pakistan. (2017). Islamic banking bulletin. Karachi, Pakistan: State Bank of Pakistan.

Suki, N. M. (1970). An empirical study of factors affecting the internet banking adoption among Malaysian consumers? The Journal of Internet Banking and Commerce, 15(2), $1-11$.

Summers, T. A., Belleau, B. D., \& Xu, Y. (2006). Predicting purchase intention of a controversial luxury apparel product. Journal of Fashion Marketing and Management: An International Journal, 10(4), 405-419. doi: https://doi.org/10.1108/13612020610701947

Taib, M. F., Ramayah, T., \& Razak, D. A. (2008). Factors influencing intention to use diminishing partnership home financing. International Journal of Islamic and Middle Eastern Finance and Management, 1(3), 235-248.

doi: https://doi.org/10.1108/17538390810901168

Taylor, S., \& Todd, P. A. (1995). Understanding information technology usage: A test of competing models. Information Systems Research, 6(2), 144-176.

doi: https://doi.org/10.1287/isre.6.2.144

Vaughan, G. M., \& Hogg, M. A. (2005). Introduction to social psychology. New South Wales, Australia: Pearson Education.

Wahyuni, S., \& Arifin, T. (2013). Knowledge as an antecedent variable of intention to use Islamic banking product. Paper presented at the International Conference on Business, Economics, and Social Sciences, Bangkok, Thailand.

World Bank Group. (2018). Islamic finance bulletin. Retrieved from https://bit.ly/2GF56iV 